\title{
Morphological and molecular characterization of garlic (Allium sativum L.) genotypes sampled from Turkey
}

\author{
Hayrettin Kuraç • Akife Dalda Şekerci $®$ • \\ Ömer Faruk Coşkun • Osman Gülşen
}

Received: 4 October 2021 / Accepted: 8 January 2022 / Published online: 2 February 2022

(C) The Author(s), under exclusive licence to Springer Nature B.V. 2022

\begin{abstract}
Garlic is a vegetable widely used both in food and as a pharmaceutical raw material in the world due to its contents. Although morphological differences are observed in garlic, which is obligatory apomictically propagated, clonal propagation causes narrowing variation, a genetic bottleneck. This situation complicates breeding programs aiming improvements in preferred agronomic characteristics. For this reason, determining the morphological and molecular differences between garlic genotypes originating from Turkey is important for breeding studies. In this study, morphological and molecular characteristics of 39 garlic genotypes, which are widely cultivated in Turkey, were determined. Kahramanmaraş 4 genotype was different from other genotypes in terms of some morphological features (fresh weight, dry weight, and bulb diameter). In the molecular characterization study, 10 Inter-Simple Sequence Repeats (ISSR) primers were used, and it was determined that the genotype TekDiş31 of Tunceli region was different from other garlic genotypes. Genetic similarity coefficient was found to be high $(0.85-1.0)$ in genotypes
\end{abstract}

H. Kıraç · A. Dalda Şekerci $(\bowtie) \cdot$ O. Gülşen Department of Horticulture, Faculty of Agriculture, Erciyes University, 38280 Talas, Kayseri, Turkey e-mail: akifedalda@erciyes.edu.tr

Ö. F. Coşkun

Department of Horticulture, Faculty of Agriculture, Hatay Mustafa Kemal University, Alahan, 31060 Antakya, Hatay, Turkey except for TekDiş31 garlic genotype. In general, some garlic clones (Maraş3 and Kayseri30, Urfa33 and Topakl135, Kastamonu22 and Kastamonu28, Urfa10 and Kastamonu14, Kastamonu29 and Bademci23) were completely similar to each other, while few differences were found among others. In conclusion, this study revealed that the garlic plant, despite its clonal propagation, consisted of some level of morphological and partially molecular variation. Due to its mode of reproduction (vegetative), this variation may largely be due to point or chromosomal mutation. Furthermore, the 10 identified ISSR primers can generate valuable information for genetic diversity for use by garlic breeders.

Keywords Allium sativum L. · Garlic · Molecular Characterization $\cdot$ Morphological Characterization

\section{Introduction}

Garlic (Allium sativum L.) is one of the most important vegetables of Allium species in the Alliaceae family. Allium sativum var. sativum subspecies is the cultivated garlic consumed today (Brewster, 1994). The fresh leaves and cloves of garlic are used both raw and cooked in cooking around the world and are consumed as powder form after processing. In historical periods, garlic has been used to enhance the flavor of dishes in various cultures. It is used for its aroma, as well as a traditional medicine (Arreola et al. 2015). 
The beneficial effects of garlic on health have been known for centuries. Garlic contains water (65\%), carbohydrates (28\%), sulfur compounds (1-4\%), proteins (2\%), fibers (1.5\%) and free amino acids (1-1.5\%) (Rahman 2003). In addition, garlic contains vitamin B6, vitamin C and selenium (Borek 2001). The volatile organosulfur compounds contained in garlic provide the typical pungent aroma and are responsible for many medicinal properties (Carson 1987; Yun et al. 2014; Martins et al. 2016). Garlic naturally has antioxidant potential and anticancer nature (Adaki et al. 2014; Li et al. 2018). In addition, garlic has an antimicrobial effect (Batiha et al. 2020). Compounds in garlic have important effects on the immune system (Batiha et al. 2020). It is stated that garlic may contribute to the prevention and treatment of diseases such as obesity, cardiovascular disorders, gastric ulcer and cancer (Arreola et al. 2015; Sánchez-Sánchez et al. 2020). Garlic suppresses the production of proinflammatory cytokines such as TNF- $\alpha$ and CRP in the liver (Miki et al. 2020) and stimulates important defense cells (Arreola et al. 2015; Beni and Omidi 2018). Due to these beneficial effects of garlic on the immune system, it has been evaluated that it may also be beneficial in patients with COVID-19 (Donma and Donma 2020). Garlic also has an appetite-enhancing effect (Buckland et al. 2013). This can help alleviate the loss of appetite seen in various diseases.

Garlic is widely consumed in the world for its medicinal properties. In the world, 30.7 million tons of garlic are produced annually. China with 23.25 million tons, India with 2.91 million tons, Bangladesh with 466.4 thousand tons, Korea with 387.6 thousand tons and Egypt with 318.8 thousand tons constitute the top five countries with the highest production (Stat FAO 2019). Turkey produces 23.351 tons of fresh and 103.096 tons of dried garlic (TUIK 2020). It is important to determine the morphological and molecular characterizations of the existing genotypes in the breeding programs to ensure yield and quality increase in garlic.

Garlic, an obligate apomictic species that can reproduce asexually from garlic cloves (Bradley et al. 1996), is propagated vegetatively and garlic clones are frequently exchanged among farmers (Ipek et al. 2008a, b). Over time, these clones have adapted to different climates, resulting in an increase in diversity (Paredes et al. 2008). Therefore, there is significant phenotypic variation in existing clones (Etoh and Simon 2002; Volk and Stern 2009). This variation among garlic varieties is an important factor for the cultivation of new varieties. Therefore, the evaluation of germplasm resources is important to ensure their effective use (Kamenetsky 2007). While there is a significant variation in garlic in terms of various agronomic traits and phenotypes (Pooler and Simon 1993; Bradley et al. 1996; Panthee et al. 2006; Stavělíková 2008), genetic variation is low. The most important breeding method used in garlic is clonal selection (Lampasona et al. 2003). Clonal propagation prevented the formation of genetic differences in garlic and resulted in a genetic bottleneck.

Characterization studies in garlic are mostly based on phenotypic characteristics. However, the fact that phenotype characteristics can change in different environmental conditions creates complexity in garlic clone characterization (Bradley et al. 1996). In contrast, molecular characterization is not affected by environmental conditions, and therefore repeatable over differing environments. Different DNA techniques are used for selection in breeding studies (Coşkun et al. 2017; Uzun et al. 2017; Karaman et al. 2018; Uzun et al. 2020). In garlic, RAPD (Maass and Klaas 1995; Bradley et al. 1996; Ipek et al. 2003; Choi et al. 2003; Mario et al. 2008; Abdoli et al. 2009), AFLP (Lee et al. 2002; Lampasona et al. 2003; Ipek et al. 2003, 2005; Volk et al. 2004; Ipek et al. 2008a, b; Ovesná et al. 2011; Morales et al. 2013), SSR (Ma et al. 2009; Cunha et al. 2012), SRAP (Chen et al. 2013) and in some studies the ISSR technique (Jabbes et al. 2011; Son et al. 2012) were used. The ISSR technique examines nucleotide sequences between simple sequence repeats (Zietkiewicz et al. 1994). The most important advantages of this technique are that it does not require sequence information and uses a low rate of DNA (Parveen et al. 2016). In addition, this technique has high reproducibility, high genomic distribution, and high polymorphism can be obtained (Heidari et al. 2016). Therefore, this marker technique was used to assess genetic diversity among asexually propagated garlic clones. In this study, it is aimed to characterize different garlic clones, which are frequently preferred in some regions in Turkey, in terms of morphological and molecular properties. It is aimed to contribute to the breeding studies to be done in the future by revealing the differences between the garlic genotypes. 


\section{Materials and methods}

\section{Plant material}

In the study, 39 garlic clones collected from different parts of Turkey were used as plant material. Garlics to be used as clones, Kahramanmaraş (1-8), Kastamonu (9, 12, 14-22, 24-29), Şanlıurfa $(10,11,33)$, Kayseri $(13,30)$, Aksaray $(32,38,39))$, Birecik (36), Tunceli Tek Diş (31), Bademci (23), Kayseri Hacilar Mor (34), Nevsehir Topaklı (35) were also collected from different regions.

\section{Morphological characterization method}

Morphologically, bulb fresh weight (g), bulb dry weight $(\mathrm{g})$, bulb height $(\mathrm{mm})$, bulb diameter $(\mathrm{mm})$, clove number, clove formation status and bulb bark color measurements were performed with 10 replications from each genotype. The data were analyzed with the statistical program SAS version 9.00 (SAS Institute, USA) using the GLM procedure (PROC GLM) and mean separation was conducted with DUNCAN at $\alpha=0.05 / 0.01$ for significant treatment effect $(P \leq 0.05 / 0.01)$. We carried out ANOVA to determine the effects of the garlic genotypes on certain pomological parameters. The results obtained in the morphological characterization studies were evaluated by performing variance analysis in the SAS statistical program. A least significant difference test (LSD) was performed to determine the differences among groups.

\section{Molecular characterization method}

DNA isolation studies were carried out for molecular characterization according to and Doyle and Doyle's (1987) CTAB DNA extraction protocol modified by Gulsen et al. (2005) was used. The relative purity and concentration of the extracted DNA were estimated by the bulk DNA method on a $1 \%$ agarose gel and the final DNA concentration was adjusted to $20 \mathrm{ng} / \mu \mathrm{L}$.

For DNA amplification, ISSR primers, which were previously found to be successful and give polymorphic bands, were used. Each $15 \mu$ amplification solution contained $10 \mathrm{mM}$ Tris- $\mathrm{HCl}(\mathrm{pH} 9.0)$, $50 \mathrm{mM} \mathrm{KCl}, 0.1 \%$ TritonX-100, 1.3-1.5 mM MgCl${ }_{2}$, $0.33 \mathrm{mM}$ from each dNTP, $0.67 \mathrm{mM}$ primer, 1-unit Taq polymerase, and $15 \mathrm{ng}$ template DNA.
For molecular characterization studies, genotypes were tested with 10 ISSR primers. Each marker was visually scored as absent (0) or present (1). Data were analyzed with the Numerical Taxonomy Multivariate Analysis System (NTSYS-pc) version 2.1 software package (Exeter Software, Setauket, NY, USA). In order to determine the genetic relationship between individuals, Dice similarity coefficient was used to construct an unweighted pair group method with arithmetic average (UPGMA) dendrogram (Dice 1945).

\section{Results and discussion}

The study was conducted with 39 different garlic genotypes collected from different regions. The fresh weights of the garlic genotypes used in the study ranged from 30.45 to $98.25 \mathrm{~g}$. The highest value in terms of fresh bulb weight $(98.258 \mathrm{~g})$ was measured in Kahramanmaraş4 genotype, while the lowest value (30.449 g) was obtained from Kastamonu15 genotype (Table 1).

Dry weights of garlic genotypes ranged from 28.1 to $84.35 \mathrm{~g}$. The highest dry bulb weight $(84.349 \mathrm{~g})$ was determined in Kahramanmaraş4 genotype, and the lowest dry bulb weight $(28,080 \mathrm{~g})$ was determined in Kastamonu15 genotype (Table 1).

Kayseri Hacilar37 genotype with a fresh bulb weight of $82.88 \mathrm{~g}$ had a dry bulb weight of $59.143 \mathrm{~g}$ after drying. It was observed that this genotype dries up by losing more water than Kahramanmaraş4 and Kahramanmaraş2 genotypes. Gebologlu et al. (2017) in a study conducted on garlic, the bulb weight of 13 local genotypes was determined in the range of 17.04-41.97 g. In our study, bulb weights were found to be higher.

In this study, the bulb diameters of the genotypes were found to be between 42.15 and $68.36 \mathrm{~mm}$. The highest bulb diameter was determined in Kahramanmaraş4 genotype $(68.36 \mathrm{~mm})$, the lowest bulb diameter $(18.23 \mathrm{~mm})$ was determined in Tunceli Tek Diş31 genotype (Table 1). Wang et al. (2014) found the bulb diameter between 2.23 and $7.61 \mathrm{~cm}$ in 212 garlic samples of Chinese origin. The variation seen in bulb diameter is correlated with similar studies.

In the study, the highest bulb height was obtained from Kastamonu 9 genotype with $47.32 \mathrm{~mm}$, and the 
Table 1 Morphological measurement results of garlic genotypes

\begin{tabular}{|c|c|c|c|c|c|c|c|}
\hline Genotype & Collection sites & $\begin{array}{l}\text { Fresh Weight } \\
(\mathrm{g})\end{array}$ & Dry Weight (g) & $\begin{array}{l}\text { Bulb Diameter } \\
(\mathrm{mm})\end{array}$ & $\begin{array}{l}\text { Bulb Height } \\
(\mathrm{mm})\end{array}$ & $\begin{array}{l}\text { Number } \\
\text { of cloves } \\
\text { (pieces) }\end{array}$ & $\begin{array}{l}\text { Bulb } \\
\text { external } \\
\text { cloves }\end{array}$ \\
\hline Kahramanmaraş1 & Kahramanmaraş & $80.130 \mathrm{cb}$ & $69.779 \mathrm{bc}$ & $64.764 \mathrm{a}-\mathrm{c}$ & $38.800 \mathrm{f}-\mathrm{m}$ & $9.4 \mathrm{n}-\mathrm{p}$ & $0 \mathrm{~d}$ \\
\hline Kahramanmaraş2 & Kahramanmaraş & $77.456 \mathrm{c}-\mathrm{d}$ & $72.851 \mathrm{~b}$ & $63.236 \mathrm{~b}-\mathrm{d}$ & 39.725 e-1 & $10.5 \mathrm{i}-\mathrm{p}$ & $0 \mathrm{~d}$ \\
\hline Kahramanmaraş3 & Kahramanmaraş & $82.263 \mathrm{~b}$ & $67.325 \mathrm{~b}-\mathrm{d}$ & $62.719 \mathrm{~b}-\mathrm{e}$ & $41.097 \mathrm{c}-\mathrm{j}$ & 8.6 po & $0 \mathrm{~d}$ \\
\hline Kahramanmaraş4 & Kahramanmaraş & $98.258 \mathrm{a}$ & 84.349 a & $68.363 \mathrm{a}$ & $42.129 \mathrm{~b}-\mathrm{h}$ & $9.71-\mathrm{p}$ & $0 \mathrm{~d}$ \\
\hline Kahramanmaraş5 & Kahramanmaraş & $52.800 \mathrm{~g}-1$ & $46.400 \mathrm{~g}-\mathrm{k}$ & $59.503 \mathrm{de}$ & 34.130 no & $13.7 \mathrm{~d}-\mathrm{f}$ & $0 \mathrm{~d}$ \\
\hline Kahramanmaraş6 & Kahramanmaraş & $71.081 \mathrm{~b}-\mathrm{e}$ & $63.190 \mathrm{~b}-\mathrm{e}$ & $61.076 \mathrm{c}-\mathrm{e}$ & 39.188 e-1 & $9.5 \mathrm{~m}-\mathrm{p}$ & $0 \mathrm{~d}$ \\
\hline Kahramanmaraş7 & Kahramanmaraş & $66.276 \mathrm{~d}-\mathrm{f}$ & $53.332 \mathrm{e}-\mathrm{h}$ & $64.162 \mathrm{a}-\mathrm{d}$ & 39.486 e-1 & $8.2 \mathrm{p}$ & $0 \mathrm{~d}$ \\
\hline Kahramanmaraş8 & Kahramanmaraş & $51.941 \mathrm{~g}-\mathrm{j}$ & $40.780 \mathrm{j}-\mathrm{n}$ & $58.288 \mathrm{e}$ & $36.919 \mathrm{j}-\mathrm{o}$ & 8.7 po & $3 a-d$ \\
\hline Kastamonu9 & Kastamonu & 31.192 o & 29.164 o & $45.517 \mathrm{~h}-1$ & $47.320 \mathrm{a}$ & $12.5 \mathrm{f}-1$ & $4 \mathrm{a}-\mathrm{c}$ \\
\hline Şanlıurfa10 & Şanlıurfa & $38.336 \mathrm{k}-\mathrm{o}$ & $36.905 \mathrm{k}-\mathrm{o}$ & $47.018 \mathrm{~g}-\mathrm{k}$ & $40.126 \mathrm{e}-1$ & $12.4 \mathrm{f}-\mathrm{m}$ & $3 a-d$ \\
\hline Şanlıurfa11 & Şanlıurfa & $38.524 \mathrm{k}-\mathrm{O}$ & $35.915 \mathrm{k}-\mathrm{O}$ & $46.589 \mathrm{~g}-\mathrm{k}$ & $44.894 \mathrm{a}-\mathrm{c}$ & $12.5 \mathrm{f}-1$ & $1 \mathrm{dc}$ \\
\hline Kastamonu12 & Kastamonu & $43.094 \mathrm{j}-\mathrm{o}$ & $41.113 \mathrm{i}-\mathrm{n}$ & $46.690 \mathrm{~g}-\mathrm{k}$ & $44.492 \mathrm{a}-\mathrm{d}$ & $13.6 \mathrm{c}-\mathrm{h}$ & $1 \mathrm{dc}$ \\
\hline Kayseri13 & Kayseri & 32.220 on & 30.365 on & $42.149 \mathrm{k}-1$ & $41.326 \mathrm{c}-\mathrm{i}$ & $12.3 \mathrm{f}-\mathrm{n}$ & $0 \mathrm{~d}$ \\
\hline Kastamonu14 & Kastamonu & $33.844 \mathrm{~m}-\mathrm{o}$ & $32.477 \mathrm{~m}-\mathrm{o}$ & $43.576 \mathrm{j}-1$ & $39.039 \mathrm{e}-1$ & $11.4 \mathrm{~g}-\mathrm{o}$ & $2 b-d$ \\
\hline Kastamonu15 & Kastamonu & 30.449 o & $28.080 \mathrm{o}$ & 40.8081 & $36.747 \mathrm{k}-\mathrm{o}$ & 9.9 k-p & $3 a-d$ \\
\hline Kastamonu16 & Kastamonu & 50.169 g-k & $48.422 \mathrm{~g}-\mathrm{j}$ & $51.438 \mathrm{fg}$ & $44.851 \mathrm{a}-\mathrm{c}$ & $15.2 b-f$ & $1 \mathrm{dc}$ \\
\hline Kastamonu17 & Kastamonu & 43.753 i-o & $40.622 \mathrm{j}-\mathrm{n}$ & $48.215 \mathrm{~g}-\mathrm{j}$ & $42.034 \mathrm{c}-\mathrm{g}$ & 15.7 a-e & $0 \mathrm{~d}$ \\
\hline Kastamonu18 & Kastamonu & $48.242 \mathrm{~h}-1$ & $45.873 \mathrm{~h}-\mathrm{k}$ & $49.223 \mathrm{f}-\mathrm{h}$ & 40.374 d-k & $13.7 \mathrm{~d}-\mathrm{g}$ & $5 a b$ \\
\hline Kastamonu19 & Kastamonu & 42.095 i-o & $40.802 \mathrm{j}-\mathrm{n}$ & $47.590 \mathrm{~g}-\mathrm{j}$ & $43.010 \mathrm{~b}-\mathrm{f}$ & $12.6 \mathrm{f}-1$ & $0 \mathrm{~d}$ \\
\hline Kastamonu20 & Kastamonu & 43.430 i-o & $40.745 \mathrm{j}-\mathrm{n}$ & $47.696 \mathrm{~g}-\mathrm{j}$ & 37.867 h-n & $13.2 \mathrm{~d}-\mathrm{j}$ & $0 \mathrm{~d}$ \\
\hline Kastamonu21 & Kastamonu & $35.2691-\mathrm{o}$ & $34.1511-\mathrm{o}$ & $44.012 \mathrm{i}-1$ & $43.180 \mathrm{~b}-\mathrm{e}$ & $13.3 \mathrm{~d}-\mathrm{i}$ & $2 b-d$ \\
\hline Kastamonu22 & Kastamonu & $42.220 \mathrm{i}-\mathrm{o}$ & $39.384 \mathrm{j}-\mathrm{o}$ & $47.154 \mathrm{~g}-\mathrm{k}$ & 37.942 h-n & $17.9 \mathrm{ab}$ & $2 b-d$ \\
\hline Bademci23 & Kastamonu & 46.819 i-m & $44.254 \mathrm{~h}-1$ & $50.311 \mathrm{f}-\mathrm{h}$ & $41.134 \mathrm{c}-\mathrm{j}$ & $13.6 \mathrm{c}-\mathrm{h}$ & $2 \mathrm{~b}-\mathrm{d}$ \\
\hline Kastamonu24 & Kastamonu & $35.0151-\mathrm{o}$ & $32.092 \mathrm{~m}-\mathrm{o}$ & $43.814 \mathrm{j}-1$ & $38.481 \mathrm{~g}-\mathrm{m}$ & $17.4 \mathrm{ab}$ & $3 a-d$ \\
\hline Kastamonu 25 & Kastamonu & 39.434 j-o & $37.622 \mathrm{j}-\mathrm{o}$ & $46.735 \mathrm{~g}-\mathrm{k}$ & $42.286 \mathrm{~b}-\mathrm{g}$ & $16.3 \mathrm{a}-\mathrm{c}$ & $2 b-d$ \\
\hline Kastamonu26 & Kastamonu & 45.062 i-n & 43.133 h-m & 48.918 g-i & $46.147 \mathrm{ab}$ & $12.8 \mathrm{f}-\mathrm{k}$ & $3 a-d$ \\
\hline Kastamonu27 & Kastamonu & $37.428 \mathrm{k}-\mathrm{o}$ & $32.613 \mathrm{~m}-\mathrm{o}$ & $45.734 \mathrm{~h}-\mathrm{k}$ & $39.034 \mathrm{e}-1$ & $15.8 \mathrm{a}-\mathrm{d}$ & $0 \mathrm{~d}$ \\
\hline Kastamonu28 & Kastamonu & $35.9031-0$ & $33.6721-0$ & $45.872 \mathrm{~h}-\mathrm{k}$ & $37.291 \mathrm{i}-\mathrm{n}$ & $14.2 \mathrm{~d}-\mathrm{g}$ & $2 b-d$ \\
\hline Kastamonu29 & Kastamonu & 39.729 i-o & $38.274 \mathrm{j}-\mathrm{o}$ & $49.014 \mathrm{f}-\mathrm{i}$ & $45.031 \mathrm{a}-\mathrm{c}$ & $12.7 \mathrm{f}-\mathrm{k}$ & $0 \mathrm{~d}$ \\
\hline Kayseri30 & Kayseri & $68.705 \mathrm{c}-\mathrm{f}$ & $60.678 \mathrm{c}-\mathrm{f}$ & $62.117 \mathrm{~b}-\mathrm{e}$ & $36.0691-0$ & $9.4 \mathrm{n}-\mathrm{p}$ & $0 \mathrm{~d}$ \\
\hline TekDiş31 & Unknown & 76.958 b-d & $66.131 \mathrm{~b}-\mathrm{d}$ & $18.232 \mathrm{~m}$ & $21.198 \mathrm{p}$ & $1 \mathrm{q}$ & $0 \mathrm{~d}$ \\
\hline Aksaray32 & Aksaray & $72.448 \mathrm{~b}-\mathrm{e}$ & $61.255 \mathrm{c}-\mathrm{f}$ & $66.663 \mathrm{ab}$ & 39.740 e-1 & $12.9 \mathrm{e}-\mathrm{j}$ & $3 a-d$ \\
\hline Şanlıurfa33 & Şanlıurfa & $61.086 \mathrm{e}-\mathrm{g}$ & $51.917 \mathrm{f}-\mathrm{i}$ & $62.962 \mathrm{~b}-\mathrm{e}$ & 39.446 e-1 & $10.3 \mathrm{j}-\mathrm{p}$ & $2 b-d$ \\
\hline Hac1lar34 & Kayseri & 73.326 b-e & $63.047 \mathrm{~b}-\mathrm{e}$ & $63.634 \mathrm{a}-\mathrm{d}$ & $34.815 \mathrm{~m}-\mathrm{o}$ & 10.7 h-p & $0 \mathrm{~d}$ \\
\hline Topakl135 & Nevşehir & 73.957 b-d & $57.121 \mathrm{~d}-\mathrm{g}$ & $66.531 \mathrm{ab}$ & $40.655 \mathrm{~d}-\mathrm{k}$ & $9.5 \mathrm{~m}-\mathrm{p}$ & $1 \mathrm{dc}$ \\
\hline Birecik36 & Şanlıurfa & 46.605 i-1 & $38.955 \mathrm{j}-\mathrm{o}$ & $53.670 \mathrm{f}$ & 33.146 o & $18.0 \mathrm{a}$ & $4 a-c$ \\
\hline Hacilar 37 & Kayseri & $82.886 \mathrm{~b}$ & $59.143 \mathrm{c}-\mathrm{f}$ & $66.643 \mathrm{ab}$ & 38.685 g-m & $9.9 \mathrm{k}-\mathrm{p}$ & $6 \mathrm{a}$ \\
\hline Aksaray38 & Aksaray & $65.303 \mathrm{~d}-\mathrm{f}$ & $53.023 \mathrm{e}-\mathrm{h}$ & $64.703 \mathrm{a}-\mathrm{c}$ & $35.9621-0$ & $12.1 \mathrm{~g}-\mathrm{n}$ & $4 \mathrm{a}-\mathrm{c}$ \\
\hline Aksaray39 & Aksaray & $58.208 \mathrm{f}-\mathrm{h}$ & $46.922 \mathrm{~g}-\mathrm{k}$ & $61.222 \mathrm{c}-\mathrm{e}$ & $36.366 \mathrm{k}-\mathrm{o}$ & $12.3 \mathrm{f}-\mathrm{n}$ & $4 \mathrm{a}-\mathrm{c}$ \\
\hline
\end{tabular}

*Different lettering indicates that the statistical differences between the groups are significant at the 0.01 level 
lowest bulb height was obtained from Tunceli Tek Diş31 genotype with $21.20 \mathrm{~mm}$. There is a wide variation in the number of cloves of bulbs belonging to different garlic genotypes (Table 1).

The highest number of cloves was obtained from Birecik36 type with 18 pieces, and the lowest number of cloves was obtained from Tunceli Tek Diş31 type with one clove. Figliuolo et al. (2001) stated in their study that clove characteristics are an important criterion for determining the differences between genotypes while making morphological observations in garlic. Wang et al. (2014) stated in their study that the number of cloves ranged from 1 to 13. In our study, clove numbers obtained from some genotypes were found to be higher.

External cloves in garlic bulbs are an undesirable situation that may occur due to environmental conditions as well as genetic-based changes. The tendency to form external cloves causes a distorted shape structure and reduces the market value of the products. In this study, external cloves status in garlic bulbs was determined mostly in Kayseri Hacilar37 genotype. No defective clove structures were found in 16 of 39 types investigated (Table 1). These results are consistent with similar to the studies conducted by Panthee et al. (2006).

In garlic, the bulb ground color of dry external scales ranges from white to reddish white according to UPOV parameters. In this study, three colors were observed as white, white-purple, and purple. There are 23 genotypes with completely white color and 14 genotypes with white and purple-white colors. All three-color conditions were observed in Kahramanmaraş6 genotype, while Hacılar34 genotype produced purple color in all bulbs (Table 1). Bulb ground color differed even among clones of the same genotype. The reason for this may be due to genetic inheritance as well as environmental conditions. Garlic bulbs planted close to the surface may change the bulb ground color because of contact with the cold or direct sun light.

This study showed a wide variation analyzed in terms of morphological features. In similar studies, garlic genotypes were examined in terms of different agronomic characteristics (Pooler and Simon 1993; Bradley et al. 1996; Panthee et al. 2006; Stavělíková 2008) and significant changes were detected between garlic genotypes in terms of agronomic proporties. Panthee et al. (2006) observed 4 different bulb ground colors in their study. As a result, garlic genotypes were found in a wide range in terms of morphological variation. Also, Panthee et al. (2006) carried out morphological characterization by using 179 garlic samples collected from different locations in Nepal in 2006. They found a significant variation on parameters such as bulb weight, bulb diameter, number of cloves, bulb shape and bulb ground color. Probably variations were due to varying environments and mutations.

In the study, a total of 55 bands were obtained by using 10 ISSR primers showing amplification. 47 of these bands were found to be polymorphic and 8 of them were monomorphic, and the average polymorphism value was calculated as 0.85 . All ISSR primers were found to be polymorphic, with a mean PIC of 0.2. The highest PIC value of 0.4 was obtained in primers (AGCAGC) ${ }_{3} \mathrm{G}$ and $(\mathrm{CAC})_{3} \mathrm{GC}$, and the lowest PIC value was obtained in primer $(\mathrm{AGC})_{6} \mathrm{G}$. According to the similarity dendrogram created, the similarity coefficients varied between 0.57 and 1.00 (Table 2).

Tekdiş31 is in the first main branch formed in the obtained UPGMA dendrograms. Within the second main branch, Kahramanmaraş8 genotype and others were separated. Kastamonu genotypes showed new branches on the same branch. Although most genotypes taken from Kastamonu show genetic similarity, there are also different ones. These may have occurred because of mutation. Or there may be genotypes brought from different regions and grown in Kastamonu under the name of Kastamonu-Taşköprü garlic (Fig. 1).

Some molecular studies on garlic resulted in similar findings to this study. Bradley et al. (1996) determined the similarity coefficients between 0.58 and 0.97 in their study. Paredes et al. (2008), on the other hand, determined the polymorphism rate to be 0.87 in their study on garlic. The genetic similarity rate obtained in our study was determined by Paredes et al. (2008) were found to be lower than the rates determined in their study (94-98\%).

In the studies, it was determined that the genetic similarity ratios of garlic changed in proportion to the increase in clonal reproduction of the selected genotypes. It has been observed that there is a genetic variation among the genotypes in terms of the parameters examined in this study. The most different genotype was the TekDiş31 genotype unique, which differed 
Table 2 Polymorphism and PIC values of studied ISSR primers

\begin{tabular}{|c|c|c|c|c|c|}
\hline Primary & Sequence 3'-5' & $\begin{array}{l}\text { Total Number } \\
\text { of Bands }\end{array}$ & $\begin{array}{l}\text { Number of Poly- } \\
\text { morphic Bands }\end{array}$ & $\begin{array}{l}\% \text { Polymor- } \\
\text { phism }\end{array}$ & PIC Value \\
\hline$(\mathrm{GACA}) 4$ & GACAGACAGACAGACA & 8 & 7 & 87 & 0.3 \\
\hline (GT)6GG & GTGTGTGTGTGTGG & 9 & 8 & 89 & 0.3 \\
\hline (CA)8R & CACACACACACACACAR & 2 & 2 & 100 & 0.1 \\
\hline (AGCAGC)3G & AGCAGCAGCAGCAGCAGCG & 9 & 8 & 89 & 0.4 \\
\hline (CAC)3GC & CACCACCACGC & 8 & 8 & 100 & 0.4 \\
\hline$(\mathrm{AG}) 7 \mathrm{YC}$ & AGAGAGAGAGAGAGYC & 3 & 2 & 67 & 0.1 \\
\hline (GT)8YA & GTGTGTGTGTGTGTGTYA & 4 & 3 & 75 & 0.1 \\
\hline$(\mathrm{AGC}) 6 \mathrm{G}$ & AGCAGCAGCAGCAGCAGCG & 8 & 4 & 50 & 0 \\
\hline HVH(TCC)7 & НVНТССТССТССТССТССТССТСС & 1 & 1 & 100 & 0.1 \\
\hline (TCC) $5 \mathrm{RY}$ & TCCTCCTCCTCCTCCRY & 4 & 4 & 100 & 0.1 \\
\hline
\end{tabular}

Fig. 1 The UPGMA analysis based on Dice coefficients of ISSR markers from the garlic genotypes

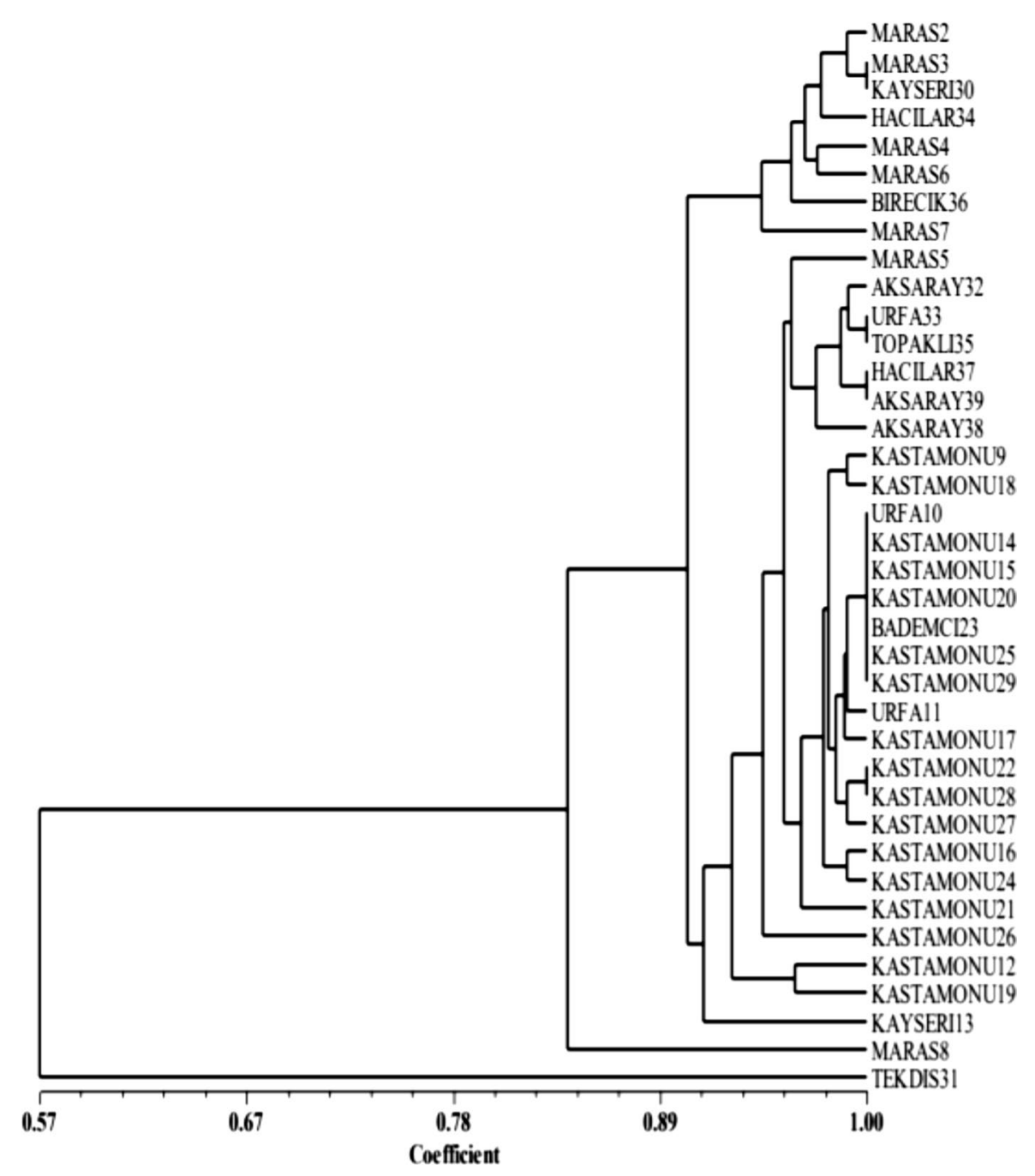


from the others in terms of features and morphology and gave a single large clove, unlike other types. It has been observed that some genotypes have different characteristics compared to other genotypes. Mantel correlation analyses between the similarity matrices of morphological and molecular markers indicated no association $(r=0.06)$. These may be caused by environmental conditions and quantitative inheritance of agronomical characters of garlic. For example, some important plant characters such as plant size and clove weigh are affected by multiple genes and the same environmental conditions may differentially affect different plant genotypes as expected.

\section{Conclusions}

In general, among the genotypes analyzed in this study, morphological and genetic variations exist. Kahramanmaraş4 genotype was significantly different in parameters such as fresh weight, dry weight and bulb diameter. In addition, it was determined that the bulb height of Kastamonu9 genotype was higher than the other genotypes and the Birecik36 genotype had a higher number of cloves. Studies show that the garlic plant has a wide morphological variation despite its clonal propagation. In this study, it was concluded that the most molecularly different plant was TekDiş31 garlic type as expected. In addition, Kastamonu9, Kahramanmaraş7 and Aksaray38 genotypes were different in terms of molecular characteristics. Determining the molecular and morphological advantages of genotypes originating in Turkey will shed light on future garlic breeding studies. In general, the garlic genotypes used in this study showed a high similarity coefficient, except for TekDiş31 garlic.

Although the gene center of garlic is Central Asia (Cunha et al. 2012), studies have been done in different continents of the world, in Asia (Ma et al. 2009; Zhao et al. 2011), Latin America (García-Lampasona et al. 2012), Africa (Jabbes et al. 2011), USA (Volk et al. 2004; Cunha et al. 2012) and Europe (Bayraktar and Dolar 2011) characterization studies were carried out among garlic genotypes. It has been determined by molecular markers that there may be genetic differences between the garlic genotypes of the same name. For example, a variety called Kastamonu garlic in Turkey has been confirmed to be two varieties using the molecular marker method (Ipek et al. 2008a, b).
Presumably, most garlic genotypes arose from mutations from a single clone. Significant variation can be seen in genetic pools, as mutations that affect important agronomic traits are easily transferred to future generations due to clonal propagation.

In this study, important data for breeding programs were obtained by determining the similarity/difference among genotypes by molecular methods. Furthermore, it was concluded that molecular markers can be a very useful tool to evaluate existing garlic genotypes and by this way large collections of garlic can be efficiently characterized.

Acknowledgements Thanks to Kayseri Sugar Company for providing garlic samples for this study.

Author's contribution KIRAC H; investigation, funding, regulation. DALDA-SEKERCI A; investigation, analyzing, writing. COSKUN OF; analysis, writing. GULSEN O; planning, supervision, funding and writing.

Funding This study was financially supported by Erciyes University Scientific Research Projects Coordinator with code of FYL-2018-7721.

Data availability All data generated or analyzed during this study are included in this published article.

\section{Declarations}

Conflict of interest The authors declare that there is no conflict of interest.

\section{References}

Abdoli M, Habibi-Khaniani B, Baghalian K, Shahnazi S, Rassouli H, NaghdiBadi H (2009) Classification of Irani an garlic (Allium sativum L.) ecotypes using RAPD marker. J Med Plants Res 8:45-51

Adaki S, Adaki R, Shah K, Karagir A (2014) Garlic: review of literature. Indian J Cancer 51:577-581

Arreola R, Quintero-Fabián S, López-Ro, RI, Flores-Gutiérrez EO, Reyes-Grajeda JP, Carrera-Quintanar L, OrtuñoSahagún D (2015) Immunomodulation and antiinflammatory effects of garlic compounds. J Immunol Res. 401630.

Batiha GES, Beshbishy AM, Wasef LG, Elewa YHA, Sagan AA, Hack MEA, Taha AE, Abd-Elhakim YM, Devkota HP (2020) Chemical constituents and pharmacological activities of garlic (Allium sativum L.): a review. Nutrients $12: 872$

Bayraktar H, Dolar FS (2011) Molecular identification and genetic diversity of Fusarium species associated with onion fields in Turkey. J Phytopathol 159:28-34

Beni MA, Omidi M (2018) Effect of short-term garlic supplementation on CD4 and CD8 factors in young karate athletes after intense exercise session. CMJA 7:2041-2051 
Borek C (2001) Antioxidant health effects of aged garlic extract. J Nutr 131:1010-1015

Bradley KF, Rieger MA, Collins GG (1996) Classification of Australian garlic cultivars by DNA fingerprinting. Aust J Exp Agric 36:613-618

Brewster JL (1994) Onion and other vegetable Alliums. CAB International, UK, p 236

Buckland NJ, Finlayson G, Hetherington MM (2013) Slimming starters: intake of a dietcongruent food reduces meal intake in active dieters. Appetite 71:430-437

Carson JF (1987) Chemistry and biological properties of onions and garlic. Food Rev Int 3:71-103

Chen SX, Zhou J, Chen Q, Chang YX, Du JN, Meng HW (2013) Analysis of the genetic diversity of garlic (Allium sativum L.) germplasm by SRAP. Biochem Syst Ecol 50:139-146

Choi HS, Kim KT, Ahn YK, Kim DS, Woo JG, Lim YP (2003) Analysis of genetic relationships in garlic germplasm and fertile garlic by RAPD. J Korean Soc Horti Sci 44:595-600

Coskun OF, Gülşen O, Dalda-Şekerci A, Yetişir H, Pinar H (2017) Bazı çerezlik kabak hatlarında SSR markır analizi. Akademik Ziraat Dergisi 6:151-156

Cunha CP, Hoogerheide ES, Zucchi MI, Monteiro M, Pinheiro JB (2012) New microsatellite markers for garlic, Allium sativum (Alliaceae). Am J Bot 99:e17-e19

Dice LR (1945) Measures of the amount of ecologic association between species. Ecology 26:297-302

Donma MM, Donma O (2020) The effects of Allium sativum on immunity within the scope of COVID-19 infection. Med Hypotheses 144:109934

Doyle JJ, Doyle JL (1987) A rapid DNA isolation procedure for small quantities of fresh leaf tissue. Phytochem Bull 19:11-15

Etoh T, Simon PW (2002) Diversity, fertility and seed production of garlic. allium crop science: recent advances. CABI Publishing, Walling ford UK, pp 101-117

Figliuolo G, Candido V, Logozzo G, Miccolis V, Zeuli PS (2001) Genetice valuation of cultivated garlic germplasm Allium sativum L. and A. Ampeloprasum L. Euphytica 121:325-334

García-Lampasona S, Asprelli P, Burba JL (2012) Genetic analysis of a garlic (Allium sativum L.) germplasm collection from Argentina. Sci Hortic 138:183-189

Geboloğlu N, Karabekiroğlu DS, Doksöz S (2017) Tokat sarımsağının morfolojik ve moleküler karekterizasyonu. J Acad Agric 6:131-136

Gulsen O, Shearman RC, Vogel KP, Lee DJ, Baenziger PS, Heng Moss T, Budak H (2005) Nuclear genome diversity and reelationships among naturally occurring buffalograss genotypes determined by sequence- related amplified polymorphism. Hortscience 40:537-541

Heidari FE, Rahimmalek M, Mohammadi S, Ehtemam MH (2016) Genetic structure and diversity of ajowan (Trachyspermum ammi) populations based on molecular morphological markers and volatile oil content. Ind Crops Prod 92:186-196

Ipek M, Ipek A, Simon PW (2003) Comparison of AFLPs, RAPD markers, and isozymes for diversity assessment of garlic and detection of putative duplicates in germplasm collection. J Am Soc Hort Sci 128:246-252
Ipek M, Ipek AS, Almquist G, Simon PW (2005) Demonstration of linkage and development of the first low-density genetic map of garlic, based on AFLP markers. Theor Appl Genet 110:228-236

Ipek M, Ipek A, Simon PW (2008a) Rapid characterization of garlic clones with locus-specific DNA markers. Turk J Agric For 32:357-362

Ipek M, Philipp AI, Simon W (2008b) Molecular characterization of Kastamonu garlic: an economically important garlic clone in Turkey. Sci Hortic 115:203-208

Jabbes N, Geoffriau E, Le Clerc V, Dridi B, Hannechi C (2011) Inter simple sequence repeat fingerprints forassess genetic diversity of Tunisian garlic populations. J Agric Sci 3(4):77-85

Kamenetsky R (2007) Garlic: botany and horticulture. Hort Rev 33:123-172

Karaman K, Dalda-Sekerci A, Yetisir H, Gulsen O, Coskun OF (2018) Molecular, Morphological and Biochemical Characterization of Some Turkish Bitter Melon (Momordica charantia L.) Genotypes. Ind Crops Prod 123:93-99

Lampasona GS, Martınez L, Burba JL (2003) Genetic diversity among selected Argentinean garlic clones (Allium sativum L.) using AFLP (Amplified Fragment Length Polymorphism) Source. Euphytica 132:115-119

Lee MK, Lim YP, Bang JW (2002) Genetic analysis of garlic (Allium sativum L.) cultivars using AFLP. Korean J Genet 24:75-81

Li Z, Le W, Cui Z (2018) A novel therapeutic anticancer property of raw garlic extract via injection but not ingestion. Cell Death Discov 4:1-10

Ma KH, Kwag JG, Zhao W, Dixit A, Lee GA, Kim HH, Ji JJ (2009) Isolation and characteristics of eight novel polymorphic microsatellite loci from the genome of garlic (Allium sativum L.). Sci Hortic 122:355-361

Maass HI, Klaas M (1995) Intraspecific differentiation of garlic (Allium sativum L.) by isozyme and RAPD markers. Theor Appl Genet 91:89-97

Mario PC, Viviana BV, Marıa IA (2008) Low genetic diversity among garlic accessions detected using RAPD. Chil J Agric Res 68:3-12

Martins N, Petropoulos S, Ferreira ICFR (2016) Chemical composition and bioactive compounds of garlic (Allium sativum L.) as affected by pre- and post-harvest conditions: a review. Food Chem 211:41-50

Miki S, Suzuki J, Kunimura K, Morihara N (2020) Mechanisms underlying the attenuation of chronic inflammatory diseases by aged garlic extract: involvement of the activation of AMP-activated protein kinase (Review). Exp Therap Med 19:1462-1467

Morales RG, Resende JT, Resende FV, Delatorre CA, Figueiredo AS, DaSilva PR (2013) Genetic divergence among Brazilian garlic cultivars based on morphological characters and AFLP markers. Genet Mol Res 12:270-281

Ovesná J, Ku-cera L, Horní-cková J, Svobodová L, Stav-elíková H, Velí-sek J, Milella L (2011) Diversity of s-alk (en) ylcysteinesul foxide content within a collection of garlic (Allium sativum L.) and itsassociation with the morphological and genetic background assessedby AFLP. Sci Horticamsterdam 129:541-547

Panthee DR, Kc RB, Regmi HN, Subedi PP, Bhattarai S, Dhakal J (2006) Diversity analysis of garlic (Allium 
sativum L.) germplasms available in Nepal based on morphological characters. Genet Resour Crop Evol 53:205-212

Paredes CM, Becerra VV, González AMI (2008) Low genetic diversity among garlic (Allium sativum L.) accessions detected using random amplified polymorphic DNA (RAPD). Chil J Agric 68:3-12

Parveen I, Gafner S, Techen N, Murch SJ, Khan IA (2016) DNA barcoding for the identification of botanicals in herbal medicine and dietary supplements: strengths and limitations. Planta Med 82:1225-1235

Pooler MR, Simon PW (1993) Characterization and classification of isozyme and morphological variation in a diverse collection of garlic clones. Euphytica 68:121-130

Rahman K (2003) Garlic and aging: new insights into an old remedy. Ageing Res Rev 2:39-56

Sánchez-Sánchez MA, Zepeda-Morales ASM, Carrera-Quintanar L, Viveros-Paredes JM, Franco-Arroyo NN, GodínezRubí M, Ortuño-Sahagun D, López-Roa RI (2020) Alliin, an Allium sativum nutraceutical, reduces metaflammation markers in DIO mice. Nutrients 12:624

Son JH, Park KC, Lee SI, Kim JH, Kim NS (2012) Species relationships among Allium species by ISSR analysis. Hortic Environ Biotech 53:256-262

Stat FAO (2019) Garlic production statistics, http://www.fao. org/statistics/en/ (date of access: 07.05.2021)

Stavelikova H (2008) Morphological characteristics of garlic (Allium sativum L.) genetic resources collection information. Hort Sci (prague) 35:130-135

TUIK (2020) www.tuik.gov.tr. Accessed on 7 May 2021

Uzun A, Coskun OF, Yaman M, Pinar H, Paris K (2017) Identification of genetic similarities among walnut (Juglans regia L.) genotypes selected from Central Anatolia region of Turkey with SRAP markers. Alatarım 16:26-34
Uzun A, Cil A, Yaman M, Coskun OF (2020) Genetic diversity and some fruit characteristics of quince genotypes collected from Kayseri region. Turk J Agric Food Sci Technol 8:318-323

Volk GM, Stern D (2009) Phenotypic characteristics of ten garlic germplasms grown at different North American locations. HortScience 44:1238-1247

Volk GM, Henk AD, Richards CM (2004) Genetic diversity among U.S. garlic clones as detected using AFLP methods. J Am Soc Hort Sci 129:559-569

Wang HP, Li XX, Shen D, Qiu Y, Song JP, Zhang XH (2014) Diversity evaluation of garlic (Allium sativum L.) clones from China based on morphological characteristics. J Plant Genet Resour 15:24-31

Yun HM, Ban JO, Park KR, Lee CK, Jeong HS, Han SB, Hong JT (2014) Potential therapeutic effects of functionally active compounds isolated from garlic. Pharmacol Ther 142:183-195

Zhao WG, Chung JW, Lee GA, Ma KH, Kim HH, Kim KT, Kim SM (2011) Molecular genetic diversity and population structure of a selected core set in garlic and its relatives using novel SSR markers. Plant Breed 130:46-54

Zietkiewicz E, Rafalski A, Labuda D (1994) Genome fingerprinting by simple sequence repeat (SSR)-anchored polymerase chain reaction amplification. Genomics 20:176-183

Publisher's Note Springer Nature remains neutral with regard to jurisdictional claims in published maps and institutional affiliations. 